\title{
The Economic Costs of COVID-19 in Sub-Saharan Africa: Insights from a Simulation Exercise for Ghana
}

\author{
Sena Amewu ${ }^{1} \cdot$ Seth Asante ${ }^{1} \cdot$ Karl Pauw $^{1}$ D $\cdot$ James Thurlow $^{1}$ \\ Accepted: 21 October 2020 / Published online: 30 October 2020 \\ (c) European Association of Development Research and Training Institutes (EADI) 2020
}

\begin{abstract}
Globally, countries have resorted to social distancing, travel restrictions and economic lockdowns to reduce transmission of COVID-19. The socioeconomic costs of these blunt measures are expected to be high, especially in sub-Saharan Africa where many live hand-to-mouth and lack social safety nets. Social Accounting Matrix multiplier model results show that Ghana's urban lockdown, although in force for only three weeks in April 2020, has likely caused GDP to fall by $27.9 \%$ during that period, while an additional 3.8 million Ghanaians temporarily became poor. Compared to the government's revised GDP growth rate of $1.5 \%$ for 2020 , the model predicts a contraction of 0.6 to $6.3 \%$ for 2020 , depending on the speed of the recovery. The US\$200 million budgeted for Ghana's Coronavirus Alleviation Program will close only a small part of the estimated US\$ 2.3 billion GDP gap between the fast recovery scenario and government's revised GDP trajectory.
\end{abstract}

Keywords Sub-saharan africa - Ghana - Social accounting matrix multiplier model COVID-19 $\cdot$ Socioeconomic impact

\section{Introduction}

As the COVID-19 pandemic spreads across sub-Saharan Africa, the region's political leadership faces an almost impossible policy dilemma. In the absence of a vaccine and amidst concerns about precarious health systems, severe shortages of intensive care beds and ventilators, and the underlying poor health of the population (The Economist 2020; Bishop 2020), it is imperative for countries to slow down the viral spread to ensure that health systems can cope with rising patient numbers and that mortality rates are kept as low as possible. However, the instruments available to policymakers to reduce the spread of the virus are blunt, and basically entail measures that restrict the movement and physical interaction of people, or in extreme

Karl Pauw

k.pauw@cgiar.org

1 International Food Policy Research Institute, Washington, DC, USA 
cases, force certain sectors to shut down. Apart from skepticism about how well such measures would work in densely populated informal neighborhoods, they can be extremely costly from a socioeconomic standpoint. With many people in subSaharan Africa living hand-to-mouth, a sudden income shock can have devastating consequences for people's food security and health.

For this reason, government stimulus programs and social support packages should ideally complement social distancing and economic lockdown measures. These support measures can be costly, especially when considering that governments themselves can anticipate deep cuts to tax revenues as economies grind to a halt. Borrowing may be an option to some governments, but with more than half the countries in sub-Saharan Africa already exceeding the International Monetary Fund's (IMF) 55\% debt-to-GDP threshold (Onyekwena and Ekeruche 2019), the ability of countries to provide such support is severely hamstrung. The policy dilemma is perhaps best articulated by Hausmann (2020, p. 2), who remarks "the flatter you want the contagion curve to be, the more you will need to lock down your country - and the more fiscal space you will require to mitigate the deeper recession that will result".

While government has some control over these tough domestic decisions, it can do little to prevent external shocks associated with the COVID-19 pandemic. With around two-thirds of the global economy under some form of lockdown or quarantine (Deloitte 2020), global supply chains are disrupted, demand is weakened, and commodity markets are in turmoil. Countries in sub-Saharan Africa may be particularly vulnerable given low levels of economic diversification, their relative openness, and an overreliance on a limited range of export commodities for foreign exchange earnings and government revenue. With disruptions to international travel, tourism revenues in sub-Saharan Africa are expected to decline by 32\% (UNWTO 2020), while foreign direct investment could drop 30 to $40 \%$ (UNCTAD 2020). Households in sub-Saharan Africa may be directly impacted by the predicted $23 \%$ decline in private remittance receipts this year (World Bank 2020).

In parallel to concerns about health and socioeconomic costs, a concern globally is the impact that COVID-19 may have on food supply chains, whether as a result of global trade restrictions, disruptions to domestic agricultural input- and output supply systems linked to restrictions on economic activity, or rising food prices as consumers stock up or resort to panic-buying (Gakpo 2020; Glauber et al. 2020). There have also been concerns about diet quality as income losses or relative price shocks push consumption away from vegetables, fruit, and animal-source foods towards less perishable, calorie-dense staples (Headey and Ruel 2020). For this reason, global actors have been closely monitoring food trade flows and commodity prices, while governments are encouraged to ensure that restrictive measures do not adversely affect agri-food systems.

The objective in this paper is to estimate the economic costs of COVID-19 policies and external shocks in a developing country context, with a focus on agri-food system impacts. Ghana is selected as a case study. Ghana recorded its first two cases of COVID-19 infection on 12 March 2020. The government responded by gradually introducing social distancing measures, travel restrictions, border closures, and eventually a two-week "partial" lockdown in the country's largest metropolitan areas of 
Accra and Kumasi. Social distancing measures have been enforced nationwide and include bans on conferences, workshops, and sporting and religious events, as well as the closure of bars and nightclubs. All educational institutions were also closed. The partial lockdown measures in urban areas directed all residents to remain home except for essential business, prohibited non-essential inter-city travel and transport, and only essential manufacturing and services operations were permitted to continue (The Presidency 2020). At the time the lockdown was announced, Ghana's Ministry of Finance revised its GDP growth estimate for 2020 downwards from 6.8 to $1.5 \%$ (MoF 2020), although the Minister warned that growth could fall further if lockdown measures were extended. The lockdown was initially extended for a third week but was officially lifted on 20 April. Many social distancing measures remain in place nationwide, although a gradual easing of restrictions commenced in June. Ghana's borders also remain closed at the time of writing.

We estimate the economic costs of COVID-19 using a Social Accounting Matrix (SAM) multiplier model for Ghana. SAM multiplier models are ideally suited to measuring short-term direct and indirect impacts of unanticipated, rapid-onset demand- or supply-side economic shocks such as those caused by the COVID-19 pandemic. Through capturing the complex linkages between various economic sectors as well as household employment and consumption patterns, SAM multiplier models can be used to simulate the direct and indirect effects of economic shocks on domestic production, value-added (GDP), employment, and household income and poverty. Since the preliminary estimate by the Ministry of Finance (2020a, 2020) focused only on GDP, and given the extension of the lockdown, our results add value to our understanding of the wide-ranging effects of COVID-19 in Ghana.

The remainder of the paper is structured as follows. "Ghana's COVID-19 Outbreak" section provides information about Ghana's COVID-19 outbreak; "Simulating the Economic Impacts of COVID-19" section introduces the SAM multiplier model and the simulation approach; "Model Results and Discussion" section presents the model results; and "Conclusions" section concludes. Technical information about the model is provided in "Annex".

\section{Ghana's COVID-19 Outbreak}

\section{Preparedness and Response}

Ghana began preparing for the spread of COVID-19 in January 2020 with the establishment of a National Technical Coordinating Committee tasked to review the country's resilience and preparedness to manage an outbreak (MoH 2020). By early March, President Nana Akuffo-Addo committed GHф 572 million (US\$ 100 million) towards a coronavirus National Preparedness and Response Plan, which sought to strengthen the capacity of health facilities, laboratories, and points of entry to detect and control viral spread and to create public awareness. Although a World Health Organization report (WHO 2020) described Ghana's readiness to deal with the COVID-19 pandemic as "adequate", global statistics on COVID-19 hospitalization rates are sobering (CDC COVID-19 Response Team 2020): with an estimated 
200 Intensive Care Unit beds and 200 ventilators available at private and public facilities in Ghana (Arhinful 2020; GhanaWeb 2020), the country can ill afford active infections rates to spiral out of control.

Figure 1 provides a timeline of policy measures against cumulative confirmed COVID-19 cases. Ghana recorded its first two cases of COVID-19 infection on 12 March 2020. Soon thereafter, President Akufo-Addo announced nationwide travel and social restrictions effective from 16 March (The Presidency 2020). These measures included a ban on entering the country for foreign nationals travelling from countries with more than 200 COVID-19 cases; a ban on public gatherings, such as conferences, workshops, political rallies, and (some) religious activities (funeral attendance was to be limited to 25 people); and closure of universities, senior high schools, and basic schools. Businesses, retail outlets, restaurants, hotels, transport operators, and local markets could continue to operate but had to adhere to social distancing and enhanced hygiene measures. Ghana only started relaxing some of these social distancing measures at the beginning of June 2020.

Although by 23 March Ghana had only recorded 25 cases (GSS 2020), Ghana's international borders were closed, initially for a two-week period, but several further extension have been announced since then and borders remain closed at the time of writing. On 30 March, a partial lockdown was announced in Ghana's largest metropolitan areas, namely Accra (including neighboring Tema and Kasoa) and Kumasi (The Presidency 2020). The lockdown was extended for one week until 20 April. All residents were directed to remain home, only leaving for essential purchases (food, medicine, water) or essential services (banking transactions, use of public toilet facilities, or medical care). The lockdown further prohibited inter-city movement of vehicles and aircrafts for private and commercial purposes, except for those providing essential services and moving cargo. Within

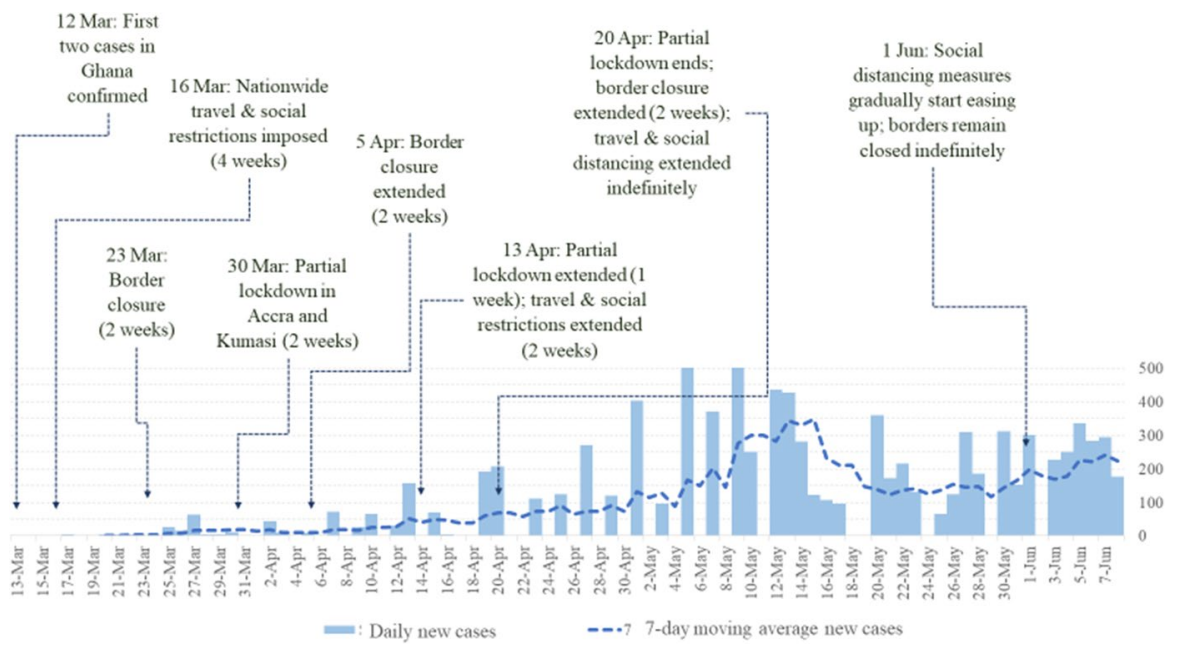

Fig. 1 Cumulative COVID-19 cases and timeline of policy response measures, mid March to mid June 2020. Source Authors' representation based on GSS (2020) and The Presidency (2020) 
city limits, passenger vehicles and taxis were instructed to reduce their numbers of passengers, resulting in an estimated 25 to 33\% reduction in capacity (Ayamga 2020).

Workers in certain categories were exempt from the stay-at-home directives. These included: (i) members of the executive, legislature and the judiciary; (ii) production, distribution and marketing of food, beverages, pharmaceuticals, medicine, paper and plastic packages; (iii) environmental and sanitation activities; (iv) staff of Volta Aluminum Company, an aluminum smelter; (v) road and railway construction workers; (vi) mining workers; (vii) fisherfolk; (viii) members of the security agencies assigned lawful duties; (ix) staff of electricity, water, telecommunications, e-commerce and digital service providers; (x) staff of fuel stations; (xi) health workers; (xii) media; and (xiii) persons in the food value chain (The Presidency 2020).

The lockdown was formally lifted after three weeks primarily due to concerns about its devastating socioeconomic impacts (The Presidency 2020). As noted, social distancing measures were gradually lifted from the beginning of June, but the country's borders remain closed.

\section{Financing and Budget Considerations}

Ghana's Ministry of Finance conducted an early rapid assessment of the likely budgetary impacts of COVID-19. On the revenue side, government expects to lose $\mathrm{GH} \not 5.68$ billion in oil revenue due to the two-thirds decline in crude oil prices. Non-oil revenues are expected to fall by $\mathrm{GH} \phi 2.25$ billion due to the slowdown in economic growth (MoF 2020) (Fig. 1). Government also faces significant unforeseen costs associated with the COVID-19 response programs, including the National Preparedness and Response Program ( $\mathrm{GH} \notin 572$ million), and the Coronavirus Alleviation Program ( $\mathrm{GH} \phi 1.20$ billion). The latter makes provision for various stimulus and support measures, including $\mathrm{GH} \phi 600$ million in the form of soft loans to small and medium enterprises, to which private sector banks will contribute a further $\mathrm{GH} \notin 400$ million; $\mathrm{GH} \phi 320$ million to supplement healthcare workers' incomes; and $\mathrm{GH} \not 280$ million for household water supply subsidies, food packages, and public grain procurement from smallholders (MoF 2020). In order to finance these costs and to cover losses in revenue, government obtained an IMF loan of US\$ 1 billion (GH $\notin 5.72$ billion) (IMF 2020b). Interest on the loan of around $\mathrm{GH} \notin 1.7$ billion will become payable this year (Fig. 2).

In summary, revenue losses and unforeseen program costs related to COVID-19 are estimated at around $\mathrm{GH} \phi 11.4$ billion, which raises the fiscal deficit from 4.7\% of projected GDP to $7.8 \%$ of revised GDP. The new IMF loan, which comes at a time when Ghana's debt stock is already GH $\phi 200$ billion or 60\% of GDP (MoF 2019), will cover about half of the COVID-19 costs and revenue losses. Government further proposes to defer interest spending on existing loans from the Bank of Ghana and to temporarily reduce or suspend payments to sovereign investment funds, such as the Stabilization Fund and the Heritage Fund. It also plans to reduce planned capital and current expenditure by GH $\not 1.25$ billion this year (MoF 2020). 


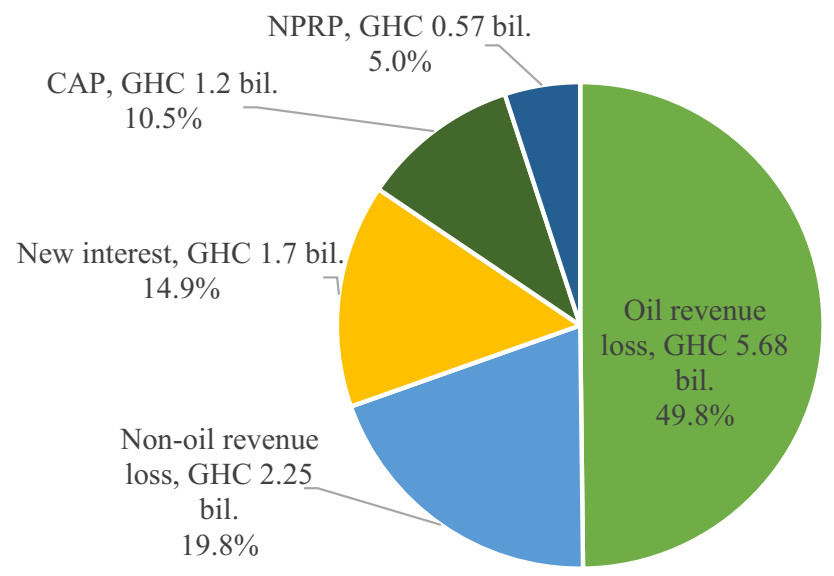

Fig. 2 Costing the COVID-19 pandemic. Source Compiled from MoF (2020). Note NPRP National Preparedness and Response Program, CAP Coronavirus Alleviation Program

\section{Protecting the Agri-Food System}

In recognition of the socioeconomic importance of the agricultural sector and the vulnerabilities of the agri-food system, the Minister of Agriculture released a press statement on 30 March explicitly exempting the agri-food system from domestic COVID-19 related restrictions (MoFA 2020). This meant (i) all farmers could continue their farming activities; (ii) input suppliers and retailers could continue distribution and sales of farm inputs; (iii) the transportation of farm inputs within lockdown zones and in the rest of the country could continue uninterrupted; (iv) food processing companies could continue production and distribution of their products; and (v) subsidized fertilizer and seed subsidies would continue to be provided through the Planting for Food and Jobs program.

Despite this pronouncement, the Ministry of Food and Agriculture (2020) acknowledged reports of unavailability of food in some markets, instances of government security personnel restricting movements of traders of farm inputs and food despite their exempt status, increases in food prices in some markets, and increased food losses in producing areas and at markets due to supply chain challenges and low patronage of markets. There are several reports of local authorities temporarily closing markets or restricting trade because patrons or traders failed to adhere to social distancing protocols (IFPRI 2020).

Supply chain challenges have also been reported. For example: the cocoa sector anticipates significant losses due to a lack of access to credit and the global market contraction (Ayitey 2020); cashew farmers experienced a 50\% price drop in the first quarter of 2020 as foreign investors were unable to travel to Ghana to procure nuts (B\&FT Online 2020); and with the planting season approaching, some analysts are concerned about commercial farmers plant less crop area than normal in anticipation of a decline in consumer demand (Goldstreet Business 2020). 
Globally, international commerce is expected to contract between 13 and 32\% in 2020 as a result of COVID-19 (Walker 2020). If these disruptions spill over into food supply chains, it may have important implications for Ghana. First, it may affect food availability directly. As elsewhere in Africa, Ghana's food needs are increasingly met through imports, with rapid increases recently being seen in processed food imports especially (Aragie et al. 2019). This places Ghana in a vulnerable position should it be required to shift to domestic supply chains on short notice.

Second, it could affect the availability of farm inputs. Should the global fertilizer supply chain be affected by COVID-19, the timing could be disastrous for Ghana since, on average, $75 \%$ of annual fertilizer needs are imported in the first two quarters of the year in time for the planting season (Africa Fertilizer 2020). Moreover, almost $80 \%$ of that fertilizer is procured through the Planting for Food and Jobs program, which subsidizes 50\% of the retail price (MoFA 2019; Africa Fertilizer 2020). Given the precarious financial position of government due to COVID-19, fertilizer suppliers may be cautious about delivering inputs on credit (Gyasi 2020), especially given the experience in 2013 when government cash flow problems led to fertilizer suppliers not being paid.

None of these agri-food system impacts are intended consequences of domestic policies. As such, we do not directly simulate supply-side restrictions on the agrifood system in the modeling exercise. However, we do measure and decompose the indirect effects of COVID-19 within the broader agri-food system. Generally, the discussion here demonstrates the importance of continually monitoring the situation on farms and in retail and wholesale markets as the agricultural sector may be impact indirectly despite policies implemented to protect the sector from the adverse effects of COVID-19.

\section{Simulating the Economic Impacts of COVID-19}

\section{Model and Data}

Social Accounting Matrix (SAM) multiplier models are ideally suited to measuring short-term direct and indirect impacts of unanticipated, rapid-onset demand- or supply-side economic shocks, such as those caused by the COVID-19 pandemic (Breisinger et al. 2009; Round 2003). At the heart of the multiplier model is a SAM, an economywide database that captures resource flows associated with all economic transactions that take place in the economy, usually over the course of a financial year. As such the SAM represents the structure of the economy at a point in time, showing the relationships between actors (i.e., productive activities, households, government, and foreign institutions) in terms of how they interact and transact via commodity and factor markets (Round 2003).

The SAM multiplier model in this study is calibrated with a 2018 SAM for Ghana, which is an update of a 2015 SAM developed jointly by Ghana Statistical Services, the Institute of Social, Statistical and Economic Research, and IFPRI (GSS, ISSER \& IFPRI 2017). Whereas the macro-framework for the SAM draws on such data sources as national accounts (GSS 2020) and global trade and balance of 
payments statistics (UNCTAD 2018; IMF 2020a) for 2018, the sector- and microlevel structure is constructed from a variety of sources from different years, including crop production estimates for 2018 (FAO 2020), household survey data from 2013 to 2014 (GSS 2014), and a supply-and-use table from 2004 (GSS 2010). The latter remains the latest available data on input-output relationships in Ghana. While the updated SAM has a 2018 base-year, multiplier results are applied to national accounts, household income, and population data for 2019 to permit an assessment of the likely impacts of COVID-19 in 2020, relative to 2019 values. This ensures comparability with current economic growth forecasts and other economic aggregates.

The SAM multiplier model provides a mechanism for estimating the effects of an external shock, typically an exogenous change in final demand for goods and services $\left(E_{\mathrm{c}}\right)$, on total supply $\left(Z_{\mathrm{c}}\right)$ of commodities $\left(c_{1}, \ldots, c_{n}\right)$. Through capturing input-output, employment relationships, and the functional distribution of income, the model also generates results on domestic production, employment, and changes in household incomes. Final demand $\left(E_{\mathrm{c}}\right)$ typically includes government consumption demand, investments, and exports. Household consumption demand may be treated as endogenous or exogenous in SAM multiplier models, depending on preferences. For the analysis here, we assume household demand is exogenous, i.e., a change in income will not result in a secondary round of consumption demand shocks. This is consistent with the short time horizon of our simulations, accounts for the ability of (some) households to maintain consumption levels in the shortrun by drawing down savings, and ultimately avoids over-estimation of the multipliers, which is a common concern in fixed-price multiplier models with endogenous household consumption (Haggblade and Hazell 1989).

A commonly used variant of the standard SAM multiplier model is a "semiinput-output" or "supply constrained" SAM multiplier model. Under a semiinput-output specification, supply in one or more sectors (e.g., $Z_{k}, k \in c_{1}, \ldots, c_{n}$ ) is treated as exogenous, with the associated final demand component $\left(E_{k}\right)$ becoming endogenous. Theoretically, such a model "closure" can be used to simulate a supply-side shock, e.g., a reduction in supply due to a mine or factory closing, but implicitly then demand would be satisfied through a reduction in net-exports (or, essentially, imports). However, this is not realistic in a COVID-19 context where global supply chains are also constrained. Since many of the restrictive COVID19 measures are simultaneously supply- and demand-side measures, i.e., supply is constrained through restrictions imposed on productive activities, while demand is reduced through limitations on what consumers may purchase, we apply changes to the exogenous demand component (i.e., $\Delta E_{\mathrm{c}}$ ) as a proxy for shocks to either supply and/or demand.

At least one potential limitation to our simulation approach relates to the fact that supply constraints cannot be imposed on sectors through forward linkages. For example, if a sector A supplies intermediate inputs to a downstream sector B, and sector A's output is reduced through a negative shock to its exogenous demand component, sector B's output will not automatically be constrained. Even if the exogenous shock exceeds the initial value of exogenous demand, the model will treat negative exogenous demand (say, exports) as a positive shock to supply (i.e., via 
imports), thus ensuring that sector B's output is not constrained by a lack of intermediate input supply. A way around this problem is to directly shock demand for sector B's output. Note, however, that the model does capture the effect of backward linkages. Thus, a decline in downstream sector B's output resulting from a shock to its exogenous demand component will lead to a decline in demand for upstream sector A's output.

A final point worth noting is that the short-run analysis period assumes that technical input-output relationships, output choices of producers, and consumption patterns of households do not change in response to the simulated shock. SAM multiplier models therefore assume prices are fixed, which is generally considered a drawback of these models. Since flexible prices and behavioral responses are incorporated into general equilibrium models, such models are often thought to be superior to fixed-price models. However, considering that the COVID-19 shocks constitute an almost catastrophic lockdown of demand and economic activities, rather than a shock to equilibrium where adjustments work through price-endogenous market mechanisms, the SAM multiplier framework is appropriate in this context, at least in the short run. For more on the equations making up SAM multiplier models, please refer to "Annex".

\section{Simulation Setup}

We distinguish between domestic policy-induced impact channels and external impact channels. As explained previously, all shocks are imposed via changes to the exogenous demand component $\left(\Delta E_{c}\right)$ of a sector. As such, our impact channels, listed in Table 1, are defined along individual sectors or clusters of sectors that are affected by the various COVID-19 related policy measures or external shocks. The model defines 86 sectors that can be mapped to impact channels, although not necessarily uniquely so-for example, the construction sector is impacted directly via the partial lockdown of the construction sector as well as via reductions in government revenue and foreign direct investments which impacts physical infrastructure spending. Underlying the 86 sectors are more detailed supply-and-use data for 175 economic sectors in Ghana. Therefore, in defining sector-level shocks across the 86 sectors we consider implications of policy prescriptions at a more detailed $175 \mathrm{sec}-$ tor-level and estimate a weighted average shock that is applied to the relevant sectors in the model.

As shown in Table 1, 18 potential impact channels are identified, although policy directives in Ghana means four of those, namely farming, mining, water and energy, and health, are fully exempt from lockdown measures. These sectors may, of course, be impact indirectly due to shocks entering the model via the remaining impact channels. Our assessment of policy measures allows us to classify shocks to impact channels as being: (i) "extreme" in the case of manufacturing, hospitality, and foreign remittances (i.e., supply shock imposed are in excess of 50\% during the lockdown period); (ii) "high" in the case of construction, trade, transport, education, sports and entertainment, and private services (30 to 50\% supply shock imposed), and (iii) "moderate" in the case of business services, government services, exports, 


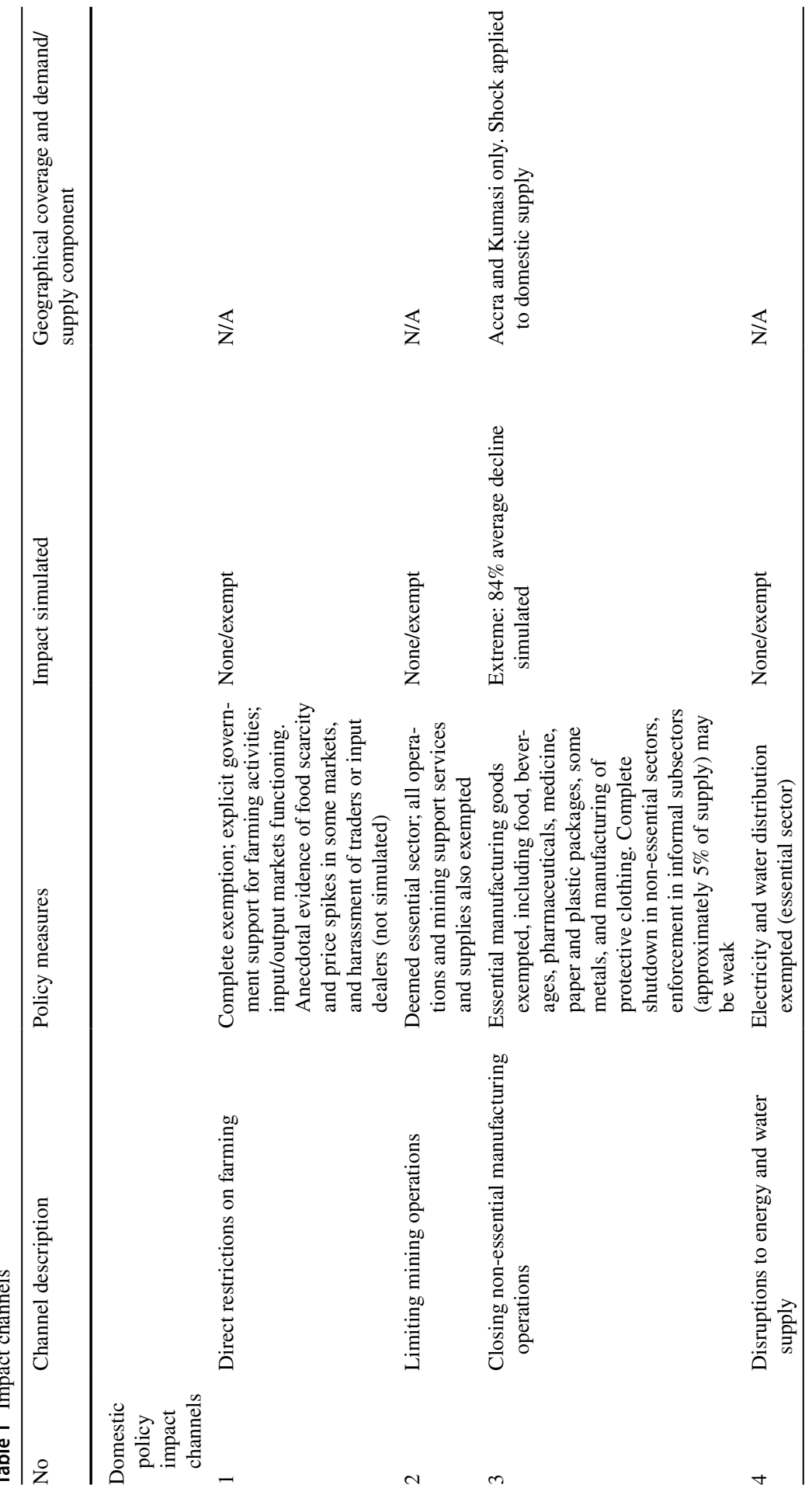

称。 


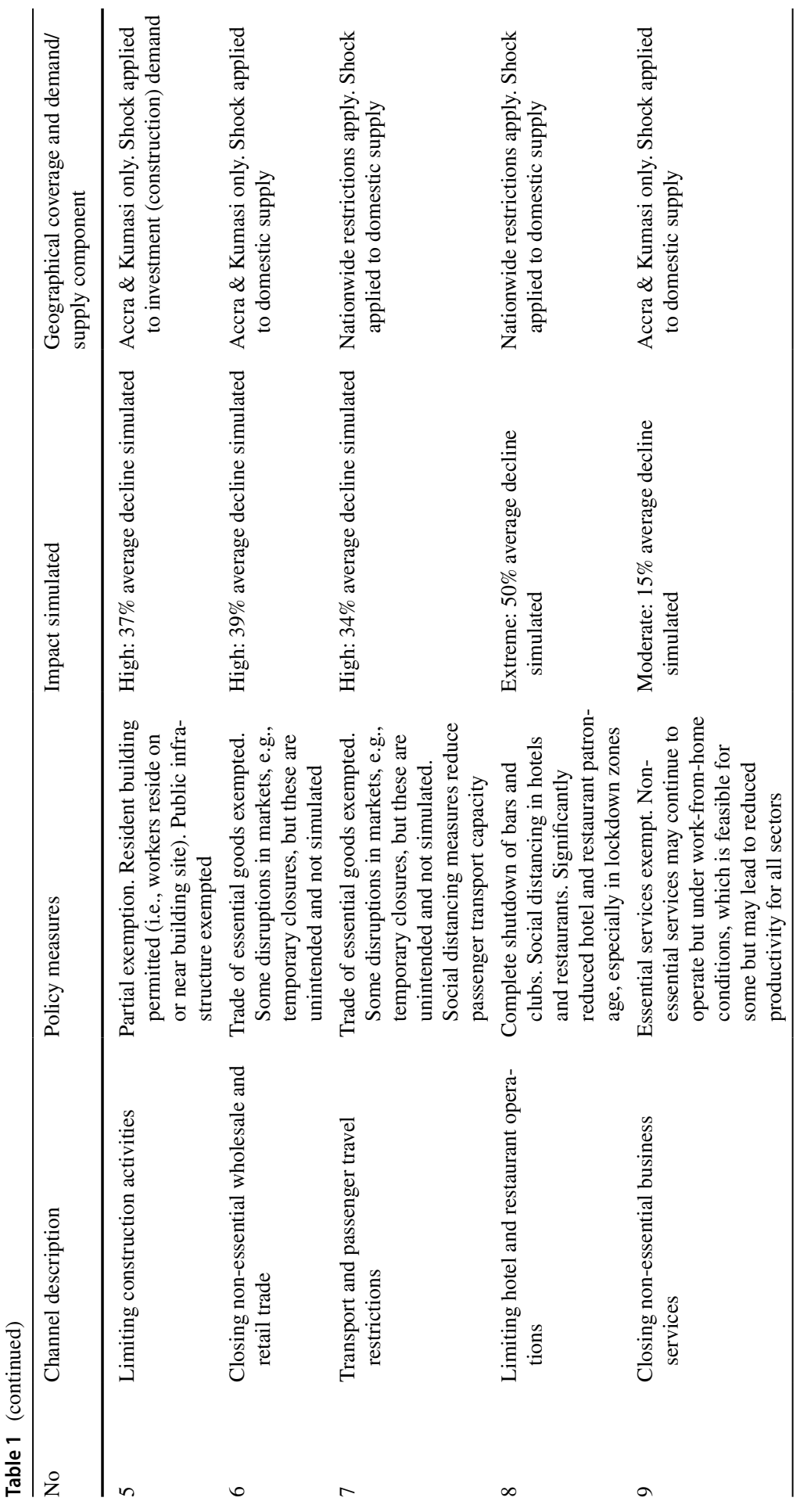




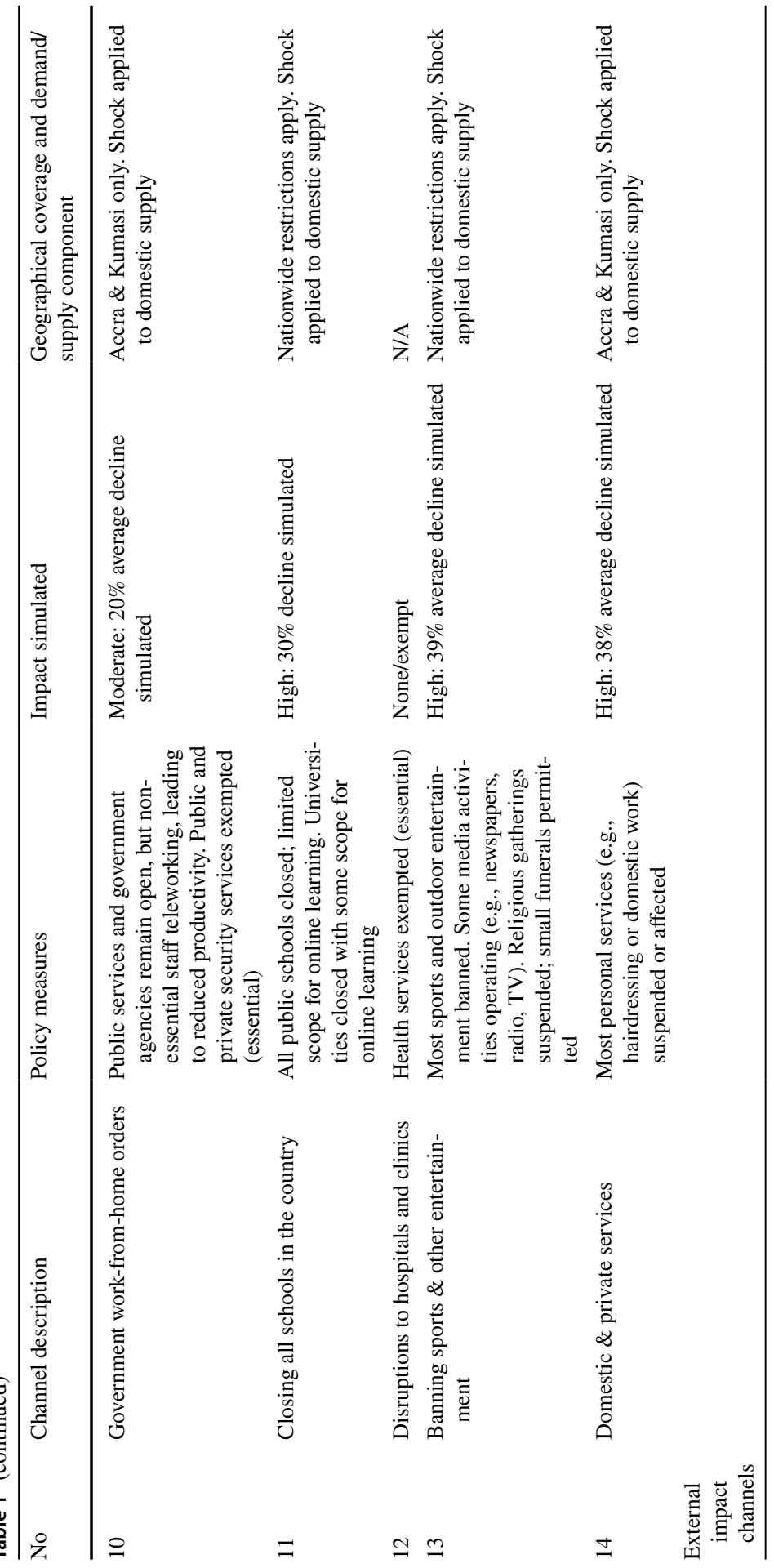

称。 


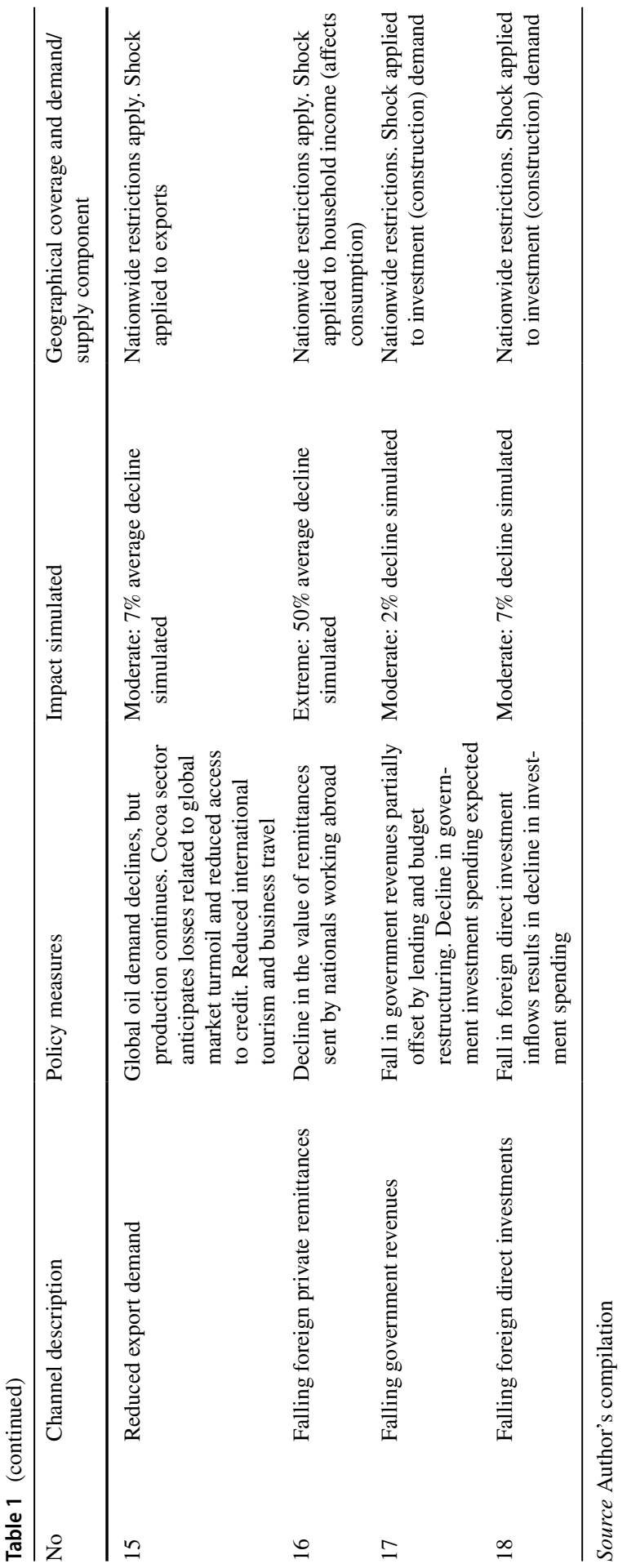


government revenue and foreign direct investments (supply shock less than $30 \%$ imposed). More detailed information about the shocks applied at the 86- and 175 -sector levels are available from the authors.

We define shocks as a percentage decline in domestic supply or in one of the final demand components. While the model is calibrated to national data, some measures only apply within the lockdown zones. In those instances, shocks are adjusted for the lockdown zone's share in sector-wide national GDP (see final column in Table 1). Accra and Kumasi are important commercial hubs in Ghana. Census and labor force data show that the specific districts affected by lockdown measures are home to $25 \%$ of Ghana's population and a similar share of the workforce. However, due to the higher-skilled nature of urban jobs, workers in the lockdown zone earn a significant wage premium over those in other urban or rural areas. Based on Labor Force Survey data (GSS 2016), we estimate that the lockdown districts account for between 28 and $46 \%$ of GDP in industry and manufacturing (average 33\%) and 37 to $41 \%$ of GDP in services (average $39 \%$ ).

\section{Scenarios and Reporting}

We first report on the anticipated impacts of COVID-19 during the lockdown period, which in the case of Ghana was in force for three weeks from 30 March to 20 April. When calculating percentage losses in national or sectoral GDP or in household income, the denominator (baseline value) is scaled to the lockdown period and adjusted for seasonal fluctuations based on historical quarterly GDP data. The second set of results looks at the impacts over the 2020 calendar year, starting in quarter one (i.e., before COVID-19) and extending through quarter four. Following the lockdown period, we assume policy measures are either lifted quickly, resulting in a fast recovery, or gradually, resulting in a slow recovery (Table 2). The fast and slow recovery scenarios may equally represent a scenario where economic actors, due to concerns for their own health, are slow to return to a business-as-usual scenario even as restrictions are fully lifted.

\section{Model Results and Discussion}

\section{Impacts During Lockdown}

We first consider the impact during the three-week lockdown. Figure 3 shows the impact on aggregate GDP and its components. The largest losses, in absolute and relative terms, are recorded in the industrial $(-26.8 \%)$ and services $(-33.1 \%)$ sectors, which contribute over $90 \%$ of the recorded $27.9 \%$ loss in national GDP during the lockdown period (left panel). This is equivalent to $\mathrm{GH} \phi 6.3$ billion or US\$ 1.3 billion in lost GDP during the three-week period (right panel). Ghana's lockdown period was relatively short; should it become necessary to reintroduce the lockdown again in future - a notion that is floated from time to time as the country battles to bring infections under control-every additional week 


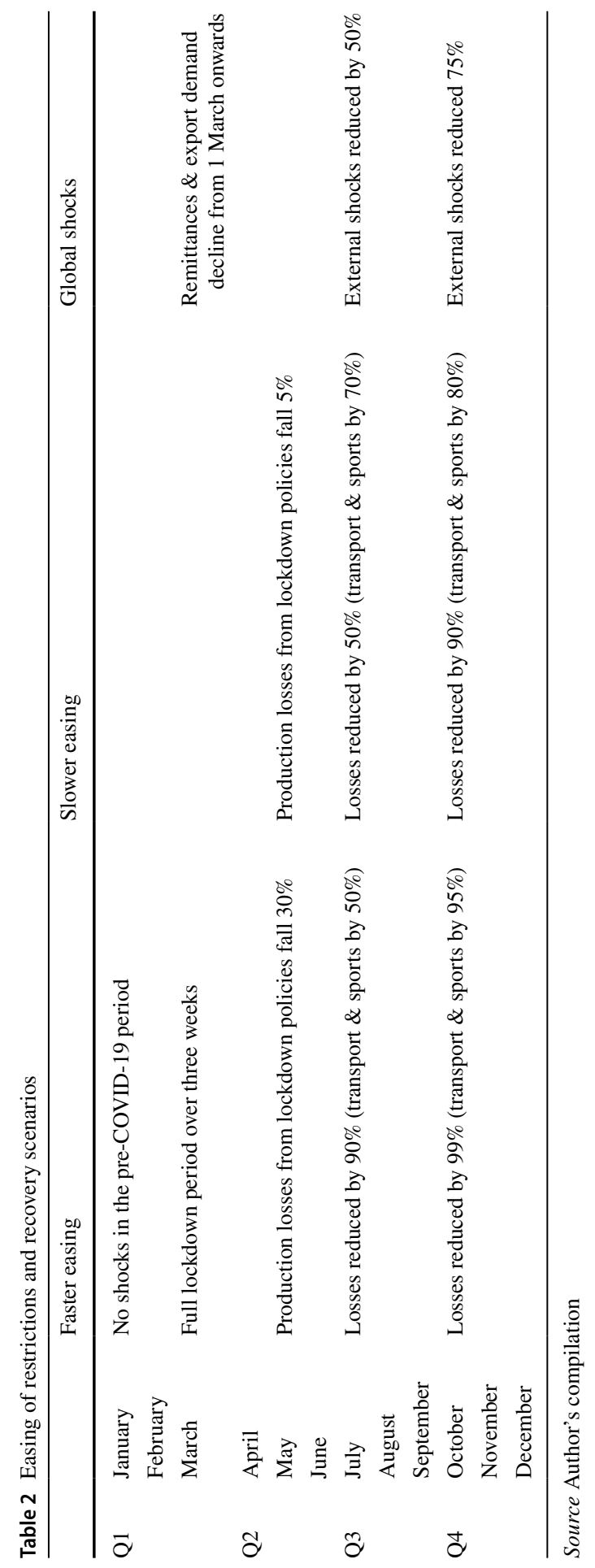




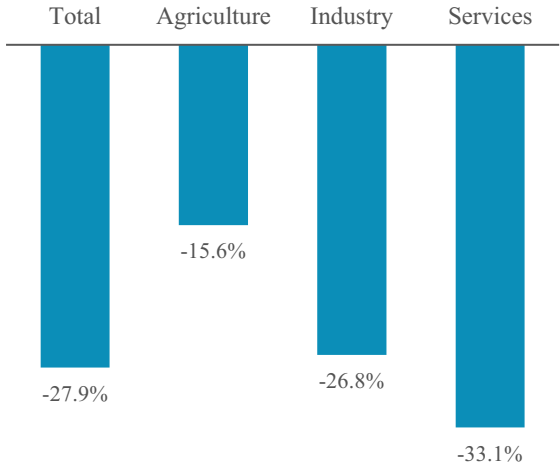

Change in GDP by sector during 3-week lockdown (\%)

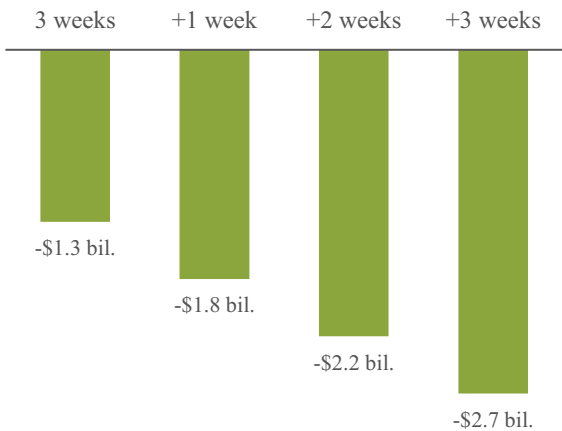

Change in total GDP by duration of lockdown (US\$ bil.)

Fig. 3 Change in GDP during three-week lockdown and hypothetical extension, by percent and value. Source Ghana SAM Multiplier Results

of lockdown would cost the economy around US\$ 450 million in lost GDP. This could vary depending on seasonal GDP adjustment factors and the exact restrictions that are imposed.

Figure 4 provides a breakdown of the contribution to total GDP losses of several of the impact channels described in Table 1. The relative contributions of these impact channels depend on the severity of the lockdown measures, the geographical scope of their implementation, the relative size of the sectors within each impact channel, and the extent of the economic linkages that exist between affected sectors and other sectors.

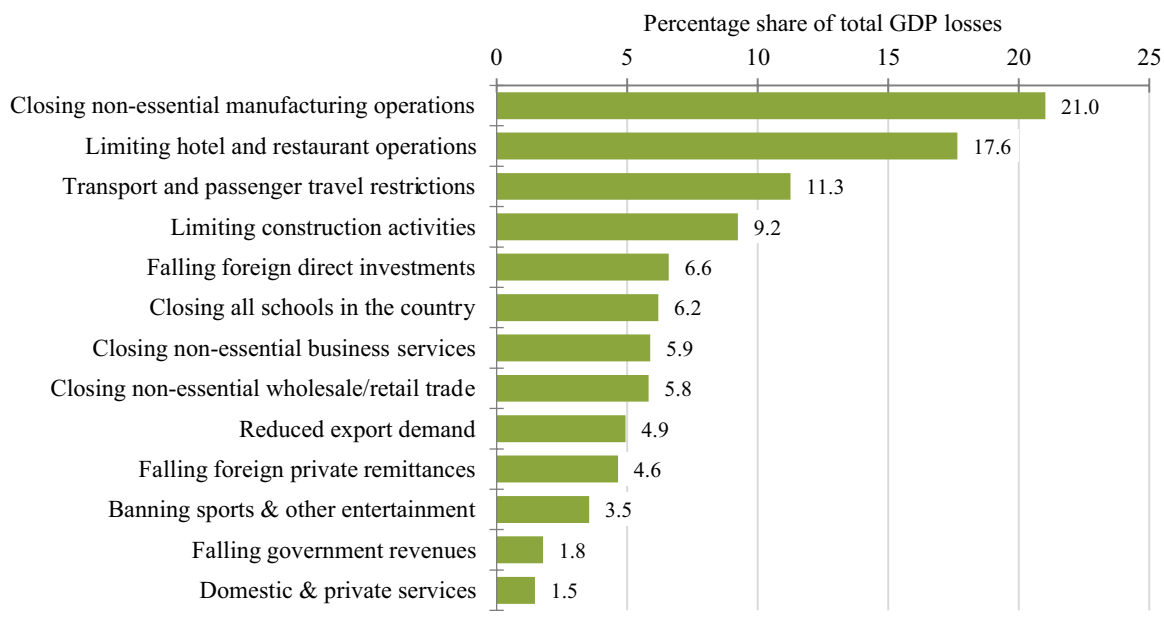

Fig. 4 Contribution of restrictions and shocks to GDP losses during lockdown. Source Ghana SAM Multiplier Results 
The severe restrictions imposed on non-essential manufacturing operations in Accra and Kumasi contribute about one-fifth to overall losses. Restrictions in the hospitality and transport sectors and domestic limitations imposed on construction activities contribute a further two-fifths. The construction sub-sector also suffers additional losses via the government and foreign direct investment impact channels, which lead to falling private and public capital stock formation.

Although primary agricultural activities are excluded from direct restrictions, the agricultural sector is not shielded from adverse effects of the lockdown, with agricultural GDP falling 15.6\% (see Fig. 3 earlier). These unintended knock-on effects of COVID-19 related policies highlight the importance of using a model framework that explicitly captures inter-industry linkages and measures indirect effects. To understand the significance of these inter-industry linkages better, it is useful to consider effects along the entire agri-food system (AFS). The AFS accounts for $36.4 \%$ of GDP in Ghana and consists of primary agriculture (19.5\% of GDP), agroprocessing (3.5\%), food services (hotels and restaurants) $(3.8 \%)$, and food trade and transport services $(9.6 \%)$. Figure 5 shows that AFS GDP losses amount $19.8 \%$ or US\$ 323 million in value terms during the lockdown period.

With respect to losses within each AFS component, we find that the food services sector, which is affected directly by social distancing measures and reduced patronage due to the fall in tourism, not only declines significantly in relative terms (-61.5\%), but also accounts for a large share of overall AFS GDP losses, despite being a relatively small subsector. Figure 6 provides a breakdown of the contribution of different impact channels to GDP losses in Ghana's agri-food system and reconfirms the substantial effect restrictions on hotel and restaurant operations have on the food system.

We next turn to household incomes. Given the nature of the lockdown measures introduced, household incomes are affected primarily via employment income losses and, to a lesser extent, via falling foreign remittances. As shown in Fig. 7, total household income falls $26.8 \%$ during the lockdown period as livelihoods are temporarily lost. If household demand were assumed endogenous, these first-round income losses would have resulted further in declines in demand and employment, and hence larger household income losses, but the distributional pattern of these losses would have been similar to what is shown the figure. In this regard, we

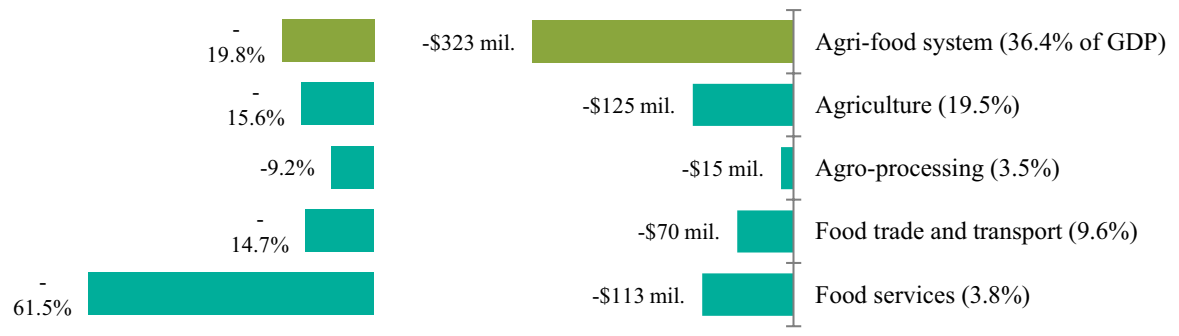

Fig. 5 Change in agri-food system GDP during lockdown period by system component, by percent and value. Source Ghana SAM Multiplier Results. Note: Figures in brackets next to labels show each component's share of national GDP 


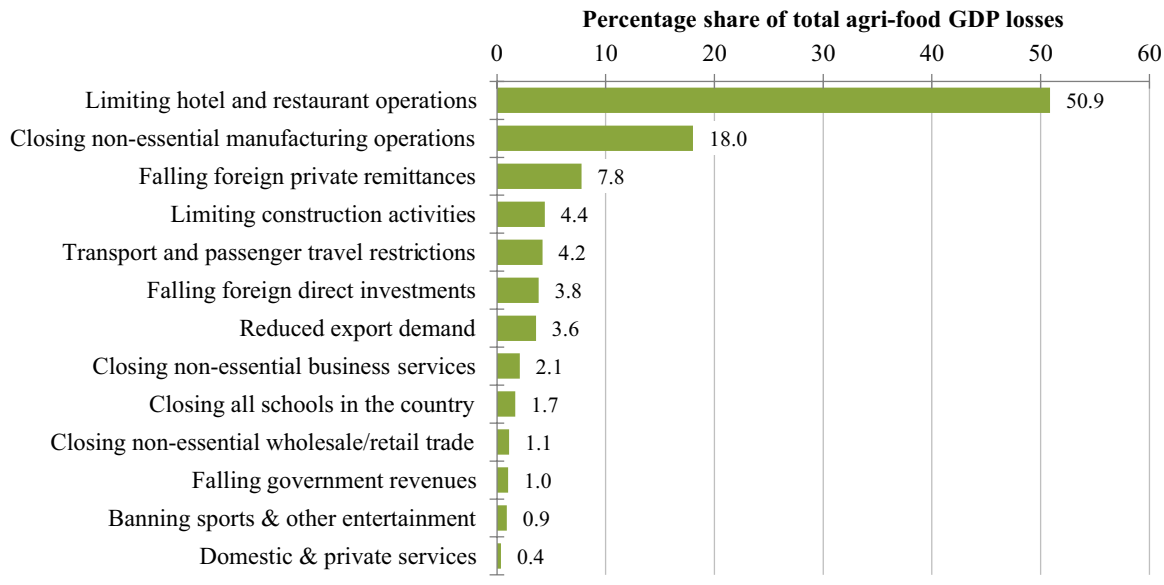

Fig. 6 Contribution of restrictions and shocks to agri-food GDP losses during lockdown. Source Ghana SAM Multiplier Results

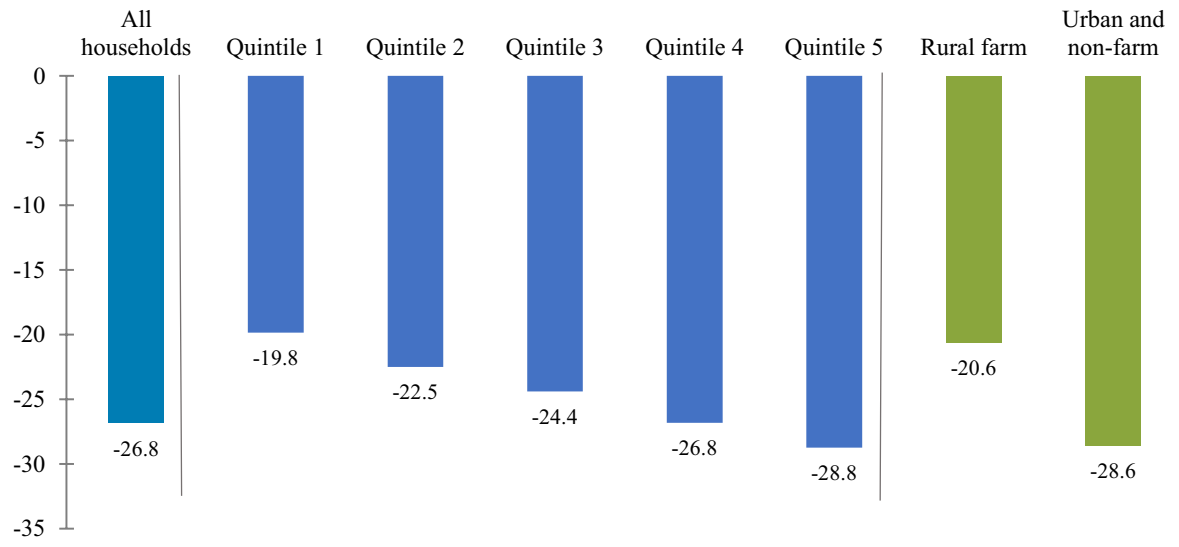

Fig. 7 Change in household incomes during lockdown, percent. Source Ghana SAM Multiplier Results

find that higher-income households suffer greater income losses than lower-income households, which reflects their stronger ties to formal sector job markets, particularly in the manufacturing and services sectors, which are the sectors most severely affected by lockdown measures. Although the lockdown primarily targets urban households and, to a more limited degree, rural non-farm households, rural farm households are affected by social distancing measures and transport restrictions imposed nationwide, as well as indirectly via spillover effects of urban lockdown measures into the agricultural sector.

Figure 8 presents the effects on poverty due to the lockdown. In generating poverty estimates, we assume that a production slowdown translates into a decline in employment income. In reality, some employers would have continued to pay 

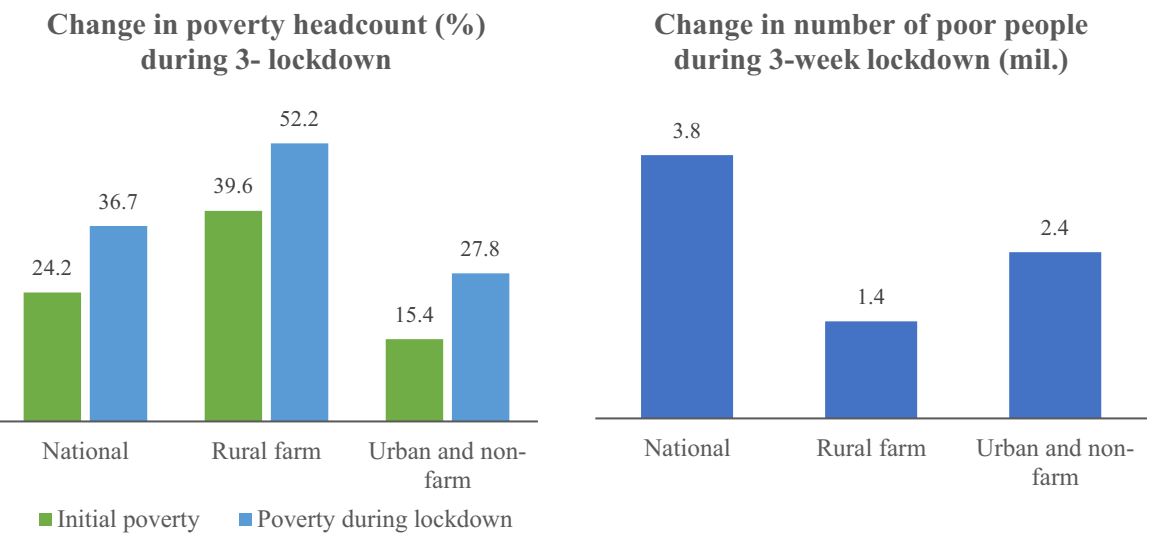

Fig. 8 Percentage change in poverty rate and change in number of poor during lockdown. Source Ghana SAM Multiplier Results

workers during lockdown or households would have been able to draw on savings to sustain consumption. As such, our result may overstate the actual experience of being poor, i.e., from the perspective of people's ability to access food. But, it nevertheless demonstrates the impact of the shock in terms of wage incomes and/ or profits foregone. We find that the national rate of poverty increases 12.5 percentage points from a base of $24.2 \%$ to $36.7 \%$, which equates to 3.8 million additional people falling below the poverty line during lockdown. Rural farm households are somewhat shielded from negative income shocks, but they still account for 37\% (1.4 million) of those that fall into poverty. This is because many rural farm households have levels of consumption just above the national poverty line, so are more vulnerable to falling into poverty due to adverse income shocks.

\section{Recovery Scenarios}

Whereas the earlier results report on the shocks experienced during Ghana's threeweek lockdown period, we also measure the likely annual impacts of COVID-19 under two scenarios: a fast recovery scenario, which assumes restrictive measures are quickly lifted and business activities rapidly return to pre-crisis levels, and a slow recovery which assumes a more gradual easing of restrictions and a tentative return to business-as-usual (see Table 2). GDP results are shown in Fig. 9. With the full lockdown only commencing towards the end of the quarter one (Q1), the loss in that quarter is minimal $(-0.7 \%)$. The biggest impact is felt in Q2 when the actual lockdown is imposed, with an average loss of 24.2 to $27.4 \%$ in quarterly GDP. (Note that these percentage losses are slightly lower than those reported in Fig. 3, because we account here for some restrictions being eased in the immediate post-lockdown period that still falls in Q2).

Further easing of restrictions in Q3 and Q4 result in losses ranging from 6.9 to $15.9 \%$ and 2.2 to $4.9 \%$, respectively, depending on the speed of recovery. Our estimated weighted average loss in GDP for the calendar year ranges from 8.6 to 


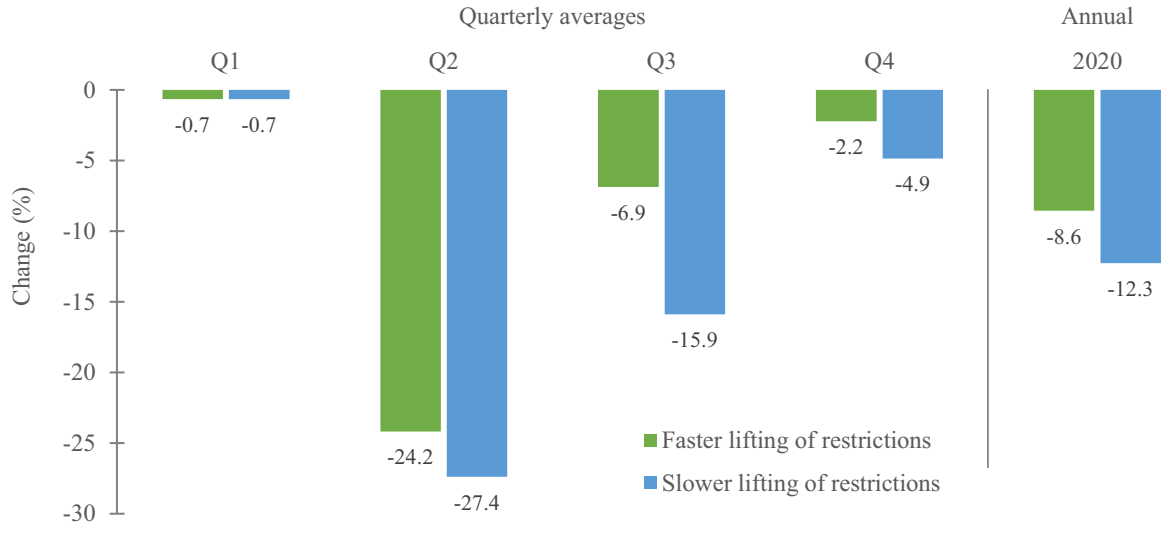

Fig. 9 Change in GDP relative to baseline in 2020. Source Ghana SAM Multiplier Results

$12.3 \%$, which translates to a year-on-year real GDP contraction of 2.3 to $6.3 \%$ for 2020. Government's own expectation is a slowdown in growth from 6.8 to $1.5 \%$ this calendar year (Fig. 10). These results suggest the GDP revision may have been too optimistic, although the projection by government was done at a time when the lockdown was planned to last for only two weeks. Moreover, that our model framework captures both direct and indirect effects of COVID-19 may also explain the less optimistic outlook shown in our projections.

Compared to the 12.5 percentage point decline in the poverty rate during lockdown, Fig. 11 shows how the poverty rate gradually returns to the baseline (or precrisis) poverty rate during the period from Q2 to Q4. By the end of the calendar year, the poverty rate will likely be between 0.8 and 1.7 percentage points higher than in the baseline. However, it is evident that millions of Ghanaians will suffer deprivations during Q2 and Q3 and will require government support.

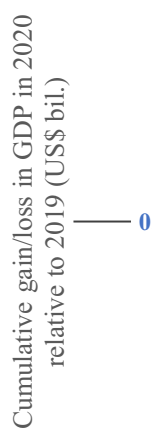

End 2019

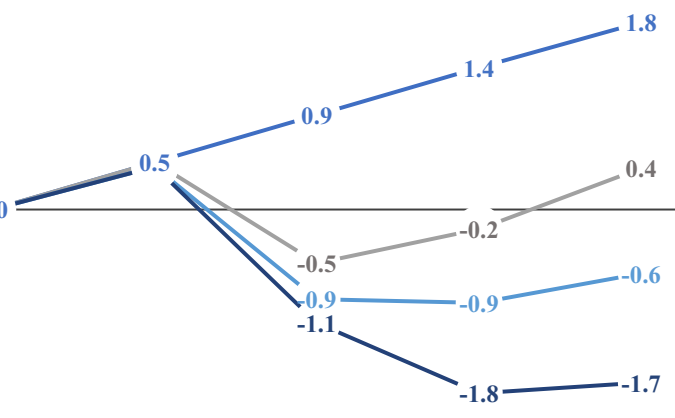

Q3
Government projected real GDP growth $6.8 \%$

Government revised real GDP growth $1.5 \%$

COVID-19 fast recovery scenario $-2.3 \%$ growth

COVID-19 slow recovery scenario $-6.3 \%$ growth

Fig. 10 Projected cumulative GDP losses in 2020 relative to 2019. Source Ghana SAM Multiplier Results 

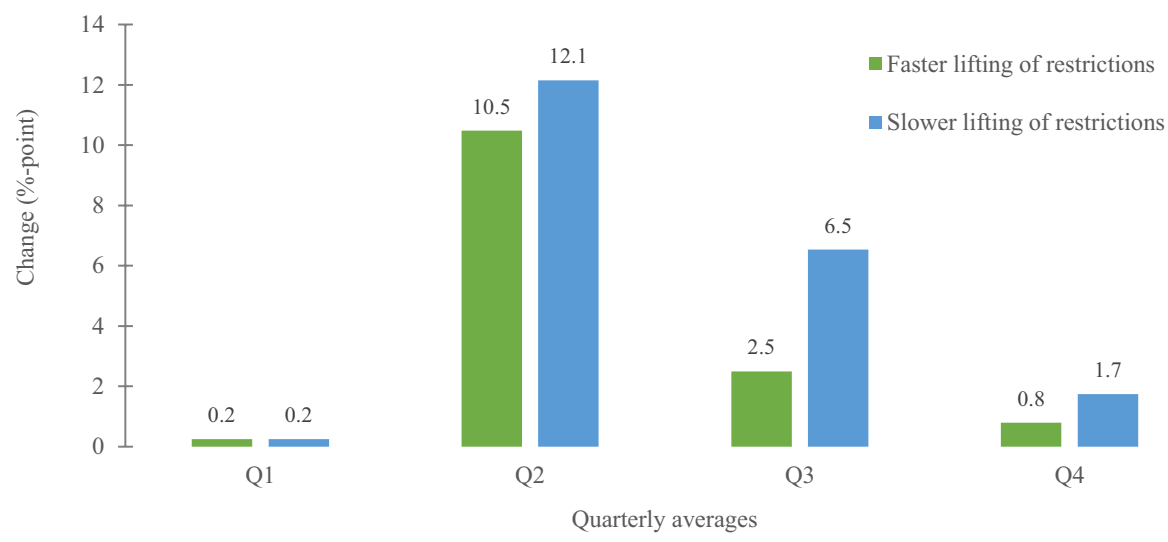

Fig. 11 Change in poverty headcount rate relative to baseline in 2020.n Source Ghana SAM Multiplier Results

Future analyses should consider the mitigating effects of the household support programs that government has established as part of its Coronavirus Alleviation Program, which include availability of government-backed soft loans, subsidized water rates and income supplements to healthcare workers (see "Financing and Budget Considerations" section). Not much is known about the targeting of these measures or the rate at which funds are being disbursed. However, the US\$200 million budgeted for the Coronavirus Alleviation Program will close only a small part of the estimated US\$2.3 billion GDP gap between our fast recovery scenario and government's revised GDP trajectory, and unless very well targeted may do little to alleviate the short-term poverty effects of COVID-19.

\section{Conclusions}

Following the example of countries across the globe, Ghana responded to the COVID-19 outbreak by introducing nationwide social distancing measures and travel restrictions, closing its international borders, and implementing a three-week lockdown in the country's largest metropolitan areas of Accra and Kumasi, which restricted the supply and marketing of non-essential goods and services. The objective of these restrictive measures was to limit the importation and spread of the coronavirus. As elsewhere, concerns about the economic implications of these measures were widespread and certainly not unfounded. In addition to domestic policy impacts, the global pandemic is disrupting global supply chains and economic activity, which could translate into falling exports and sharp reductions in government revenues, foreign direct investments, and private remittances.

The objective of this study is to estimate the economic costs of COVID-19 vis-à-vis output and value-added, employment incomes, household income, and poverty using a Social Accounting Matrix (SAM) multiplier model for Ghana. SAM multiplier models are ideally suited to measuring short-term direct and indirect impacts of unanticipated, 
rapid-onset demand- or supply-side economic shocks. Results from the multiplier model show that Ghana's partial lockdown, despite being implemented for a relatively short period and only in Ghana's major urban areas, will impose heavy economic costs. National GDP is estimated to fall by $27.9 \%$ during the three-week lockdown period, while agri-food system GDP losses are estimated at 19.8\%, even though the food sector is largely excluded from the restrictive COVID-19 related measures. Even as lockdown measures are now gradually being lifted, some restrictions (e.g., social distancing or border closures) are expected to remain in place for longer, while business may be slow to restart operations and reach pre-crisis production levels. Under our fast and slow recovery scenarios, we estimate that annual GDP will be 8.6 to $12.3 \%$ lower, respectively, than the baseline due to COVID-19. This implies a contraction in the GDP growth rate of between 2.3 and $6.3 \%$ in 2020, which is significantly less optimistic than the official revised growth target of $1.5 \%$.

With respect to poverty, and assuming the production slowdown during lockdown translates into a proportionate decline in employment income, we find that the national poverty headcount rate increases by 12.5 percentage points during the lockdown period from a base of $24.2 \%$. This substantial increase, albeit temporary, translates into an additional 3.8 million people falling into poverty during lockdown. Since some employers continued to pay workers during lockdown, and since some households may have had savings to fall back on to sustain consumption, our result may overstate the actual experience of being poor. Nevertheless, the results demonstrate the severity of the shock in terms of wage incomes or profits foregone.

During the rest of 2020, as households' current incomes recover to (almost) pre-crisis levels by the end of the fourth quarter, the national poverty rate will be between 0.8 and 1.7 percentage points higher than at the start of the year. While the expected recovery is good news for most households, millions of people will experience temporary hardships, especially during the second and third quarter, and will require significant and targeted government support.

Further analysis is needed to assess the impact of household support measures that have already been announced. However, many of these tend to be biased in favor of urban households, whereas our results show that around $37 \%$ of households that become poor during the lockdown period are rural farm households. Special support measures for the food system are also warranted, not only to protect rural farm livelihoods, but to ensure stable and safe food supply across all markets.

\section{Compliance with ethical standards}

Conflict of interest On behalf of all authors, the corresponding author states that there is no conflict of interest. 


\section{Annex: Social Accounting Matrix (SAM) Multiplier Model Equations}

Following the example in Breisinger et al. (2009), consider a simple two-sector SAM multiplier model represented by two demand equations, where supply $\left(Z_{1}\right.$ and $Z_{2}$ ) equals the sum of intermediate input demand, private household demand, and final demand $\left(E_{1}\right.$ and $\left.E_{2}\right)$, assumed here to include government demand, investments, and exports. Intermediate input demand is expressed as a function of domestic production, $X_{1}$ and $X_{2}$ and the relevant technical coefficients, $a_{i j}$, denote demand for commodity $i$ required per unit of commodity $j$ produced. Household demand, in turn, is a fixed share $\left(c_{i}\right)$ of income. Thus:

$$
\begin{aligned}
& Z_{1}=a_{11} X_{1}+a_{12} X_{2}+c_{1} Y+E_{1} \\
& Z_{2}=a_{21} X_{1}+a_{22} X_{2}+c_{2} Y+E_{2}
\end{aligned}
$$

Supply is made up of domestically produced and imported goods and services. We assume that domestic production $X_{i}$ is a fixed share $\left(b_{i}\right)$ of income $Z_{i}$ :

$$
X_{1}=b_{1} Z_{1} \quad \text { and } \quad X_{2}=b_{2} Z_{2}
$$

Households derive income from employment, by assumption, a fixed share $\left(v_{i}\right)$ of output:

$$
Y=v_{1} X_{1}+v_{2} X_{2} \quad \text { or } \quad Y=v_{1} b_{1} Z_{1}+v_{2} b_{2} Z_{2}
$$

Substituting (3) into (1a) and (1b) yields the following equations:

$$
\begin{aligned}
& Z_{1}=a_{11} b_{1} Z_{1}+a_{12} b_{2} Z_{2}+c_{1}\left(v_{1} b_{1} Z_{1}+v_{2} b_{2} Z_{2}\right)+E_{1} \\
& Z_{2}=a_{21} b_{1} Z_{1}+a_{22} b_{2} Z_{2}+c_{2}\left(v_{1} b_{1} Z_{1}+v_{2} b_{2} Z_{2}\right)+E_{2}
\end{aligned}
$$

Rearranging so that domestic supply components are on the left and the exogenous demand components are on the right and simplifying further yields the multiplier system of equations:

$$
\begin{aligned}
& \left(1-a_{11} b_{1}-c_{1} v_{1} b_{1}\right) Z_{1}+\left(-a_{12} b_{2}-c_{1} v_{2} b_{2}\right) Z_{2}=E_{1} \\
& \left(-a_{21} b_{1}-c_{2} v_{1} b_{1}\right) Z_{1}+\left(1-a_{22} b_{2}-c_{2} v_{2} b_{2}\right) Z_{2}=E_{2}
\end{aligned}
$$

This can be expressed in matrix format as follows:

$$
\left(\begin{array}{cc}
1-a_{11} b_{1}-c_{1} v_{1} b_{1} & -a_{12} b_{2}-c_{1} v_{2} b_{2} \\
-a_{21} b_{1}-c_{2} v_{1} b_{1} & 1-a_{22} b_{2}-c_{2} v_{2} b_{2}
\end{array}\right)\left(\begin{array}{c}
Z_{1} \\
Z_{2}
\end{array}\right)=\left(\begin{array}{c}
E_{1} \\
E_{2}
\end{array}\right)
$$

The first term in (6) is the identity matrix $(I)$ minus the coefficient matrix $(M)$, while its inverse $(I-M)^{-1}$ is known as the multiplier matrix. Thus, in matrix notation with vectors $Z$ and $E$, the final multiplier equation becomes: 


$$
Z=(I-M)^{-1} E
$$

This allows us to calculate the change in domestic supply $(Z)$ for a given change in exogenous demand $(E)$. Output multipliers (derived from the output vector, $X$ ), employment multipliers, and income multipliers (derived from the income measure, $Y$ ) are calculated through substitution. Equation (7) is generalizable for a SAM of any dimension.

Note when household demand (3) is treated as exogenous, this component of demand forms part of final demand $(E)$ and the coefficient matrix $(M)$ simply excludes the various share parameters $\left(c_{i}, b_{i}\right.$ and $\left.v_{i}\right)$.

\section{References}

Africa Fertilizer. 2020. Fertilizer statistics overview Ghana: 2015-2019. Accra, Ghana: AfricaFertilizer. org and International Fertilizer Development Center (IFDC).

Aragie, E., M. Artavia, and K. Pauw. 2019. Strategic public spending: Scenarios and lessons for Ghana. IFPRI discussion paper no. 01862 (July 2019). Washington, DC: International Food Policy Research Institute (IFPRI).

Arhinful, E. 2020. COVID-19: Ghana has 67 ventilators-Health Minister. April 1. https://citinewsro om.com/2020/04/covid-19-ghana-has-67-ventilators-health-minister/. Accessed 10 April 2020.

Ayamga, E. 2020. Coronavirus: Trotros to carry just 2 passengers per row from today. March 26. https:// www.pulse.com.gh/news/local/coronavirus-trotros-to-carry-just-2-passengers-per-row-from-today/ qqgk5n9. Accessed 13 April 2020.

Ayitey, C. 2020. Tumble of global cocoa price causes Ghana \$1bn deficit-COCOBOD. April 7. https ://www.myjoyonline.com/business/agribusiness/tumble-of-global-cocoa-price-causes-ghana-1bndeficit-cocobod/. Accessed 25 April 2020.

B\&FT Online. March. Coronavirus: Local cashew industry suffers 50\% price drop. 18 2020. https://thebf tonline.com/2020/editors-pick/coronavirus-local-cashew-industry-suffers-50-price-drop/. Accessed 26 April 2020.

Bishop, C. 2020. COVID-19-"Enormous gap" in ventilators for Africa-The worry is no one is sure how big. April 2. https://www.cnbcafrica.com/west-africa/2020/04/02/covid-19-enormous-gap-inventilators-for-africa-the-worry-is-no-one-is-sure-how-big/. Accessed 10 April 2020.

Breisinger, C., M. Thomas, and J. Thurlow. 2009. Social accounting matrices and multiplier analysis: An introduction with exercises. Food security in practice technical guide 5. Washington, DC: International Food Policy Research Institute.

CDC COVID-19 Response Team. 2020. Severe outcomes among patients with coronavirus disease 2019 (COVID-19)—United States, February 12-March 16, 2020. Morbidity and Mortality Weekly Report (MMWR) 69(12): 343-346. https://www.cdc.gov/mmwr/volumes/69/wr/mm6912e2.htm?s_ cid=mm6912e2_w. Accessed 10 April 2020

Deloitte. 2020. Economic impact of the Covid-19 pandemic on the economy of ghana: Summary of fiscal measures and deloitte views. Accra: Deloitte Ghana.

FAO. 2020. FAO statistical databases (FAOSTAT). Rome, Italy: Food and Agriculture Organization of the United Nations.

Gakpo, D.O. 2020. COVID-19 virus spread prompts food insecurity fears in Africa. March 26. https:// allianceforscience.cornell.edu/blog/2020/03/covid-19-virus-spread-prompts-food-insecurity-fears -in-africa/. Accessed 14 April 2020.

GhanaWeb. 2020. 200 ICU beds ready to contain critical Coronavirus cases-Oppong Nkrumah. March 28. https://www.ghanaweb.com/GhanaHomePage/NewsArchive/200-ICU-beds-ready-to-containcritical-Coronavirus-cases-Oppong-Nkrumah-906823. Accessed 10 April 2020.

Glauber, J., D. Laborde, and R. Vos. 2020. COVID-19: Trade restrictions are worst possible response to safeguard food security. March 27. https://www.ifpri.org/blog/covid-19-trade-restrictions-are-worst -possible-response-safeguard-food-security. Accessed 14 April 2020. 
Goldstreet Business. 2020. COVID-19 pandemic: How prepared is Ghana's rice sector? March 29. https://goldstreetbusiness.com/2020/business/agribusiness/covid-19-pandemic-how-prepared-isghanas-rice-sector/. Accessed 26 April 2020.

GSS. 2010. Supply and use table for Ghana, 2004. Accra, Ghana: Ghana Statistical Services.

GSS. 2014. 2012/13 Ghana living standards survey round 6 (GLSS6): Main report. Accra, Ghana: Ghana Statistical Services.

GSS. 2016. 2015 labor force report. Accra: Ghana Statistical Service (GSS).

GSS. 2020. Rebased 2013-2019 annual gross domestic product. Accra, Ghana: Ghana Statistical Services.

GSS. 2020. Ghana COVID-19 monitoring dashboard. April 10. https://statsghana.maps.arcgis.com/ apps/opsdashboard/index.html\#/a22ebfb6d9cb47ff9ce87619d53f68e5.

GSS, ISSER \& IFPRI. 2017. Report on the 2015 Social Accounting Matrix (SAM) for Ghana. Accra, Ghana: Ghana Statistical Services (GSS), Institute of Statistical, Social and Economic Research (ISSER) and International Food Policy Research Institute (IFPRI).

Gyasi, F., interview by K. Pauw. 2020. Fertilizer statistics expert (April 1).

Haggblade, S., and P. Hazell. 1989. Agricultural technology and farm-non-farm growth linkages. Agricultural Economics 3 (4): 345-364.

Hausmann, R. 2020. Flattening the COVID-19 curve in developing countries. March 24. https://www. project-syndicate.org/commentary/flattening-covid19-curve-in-developing-countries-by-ricardohausmann-2020-03. Accessed 8 April 2020.

Headey, D., and M. Ruel. 2020. The COVID-19 nutrition crisis: What to expect and how to protect. April 23. https://www.ifpri.org/blog/covid-19-nutrition-crisis-what-expect-and-how-protect. Accessed 26 April 2020.

IFPRI. 2020. COVID-19 policy response (CPR) portal. International Food Policy Research Institute. https://www.ifpri.org/project/covid-19-policy-response-cpr-portal. Accessed 8 June 2020.

IMF. 2020a. Balance of payments and international investment position statistics. Washington, DC: International Monetary Fund.

IMF. 2020b. Ghana: Request for disbursement under the rapid credit facility-Press release. IMF country report no. 20/110, Washington, DC: International Monetary Fund.

MoFA. 2019. Planting for Food and Jobs Campaign: Implementation modalities and campaign impact. Accra, Ghana: Directorate of Crop Services, Ministry of Food and Agriculture (MoFA), Republic of Gahana.

MoF. 2019. Budget highlights of the Government of Ghana for the 2020 financial year. Accra, Ghana: Ministry of Finance, Republic of Ghana.

MoF. 2020. Statement to parliament on the coronavirus alleviation programme. Accra, Ghana: Ministry of Finance (MoF), Republic of Ghana.

MoFA. 2020. Press statement by Hon. Minister for Food and Agriculture on the Distribution and Marketing of food items during the period of restriction. Accra, Ghana: Ministry of Food and Agriculture (MoFA), Republic of Ghana.

MoH. 2020. Press Release: Update on Preparedness on 2019 Novel Corona Virus (2019-nCOV) Outbreak. Accra, Ghana: Ministry of Health $(\mathrm{MoH})$, Republic of Ghana.

Onyekwena, C., and M.A. Ekeruche. 2019. Is a debt crisis looming in Africa? April 10. https://www. brookings.edu/blog/africa-in-focus/2019/04/10/is-a-debt-crisis-looming-in-africa/. Accessed 8 April 2020

Round, J. 2003. Social accounting matrices and SAM-based multiplier analysis. In Techniques and tools for evaluating the poverty impact of economic policies, ed. F. Bourguignon and L.A. Pereira-da-Silva. Washington, DC: World Bank and Oxford University Press.

The Economist. 2020. Africa is woefully ill-equipped to cope with Covid-19. March 26. https://www. economist.com/middle-east-and-africa/2020/03/26/africa-is-woefully-ill-equipped-to-cope-withcovid-19. Accessed 8 April 2020.

The Presidency. 2020. Speeches. March 15. https://presidency.gov.gh/index.php/briefing-room/speec hes. Accessed 10 April 2020.

UNCTAD. 2020. Coronavirus could cut global investment by 40\%, new estimates show. March 26. https://unctad.org/en/pages/newsdetails.aspx?OriginalVersionID=2313. Accessed 27 April 2020.

UNCTAD. 2018. Trade analysis information system. Geneva, Switzerland: United Nations Conference on Trade and Development. 
UNWTO. 2020. Impact assessement of the COVID-19 outbreak on international tourism. March 27. https ://www.unwto.org/impact-assessment-of-the-covid-19-outbreak-on-international-tourism. Accessed 25 April 2020.

Walker, A. 2020. Coronavirus: 'Drop in global trade to be worse than 2008 crisis'. April 8. https://www. bbc.com/news/business-52211919. Accessed 26 April 2020.

WHO. 2020. WHO African Region COVID-19 readiness status v2. April 10.

World Bank. 2020. World Bank predicts sharpest decline of remittances in recent history. April 22. https ://www.worldbank.org/en/news/press-release/2020/04/22/world-bank-predicts-sharpest-decline-ofremittances-in-recent-history. Accessed 24 April 2020.

Publisher's Note Springer Nature remains neutral with regard to jurisdictional claims in published maps and institutional affiliations. 